\title{
Evaluation and Analysis of Oil Shale in Quseir-Safaga and Abu-Tartur Western Desert, Egypt
}

\author{
El-Abbas Moustafa', Ahmed Noah'2, Adel Salem², Ahmed Nehad', Maureen Amir'2, \\ Mohamed Nosr ${ }^{2}$, Radwa Awad ${ }^{2}$, Mahmoud Gomaa', Marawan Moussa ${ }^{2}$ \\ ${ }^{1}$ Production Department, Egyptian Petroleum Institute, EPRI, Nasr City, Cairo, Egypt \\ ${ }^{2}$ Petroleum and Energy Science Department, Faculty of Engineering, American University in Cairo, Cairo, Egypt \\ Email: moustafa abs@hotmail.com, ahmednoah@aucegypt.edu, adel.salem@aucegypt.edu
}

Received 24 February 2014; revised 23 March 2014; accepted 11 April 2014

Copyright (C 2014 by authors and Scientific Research Publishing Inc.

This work is licensed under the Creative Commons Attribution International License (CC BY). http://creativecommons.org/licenses/by/4.0/

CC) (i) Open Access

\begin{abstract}
Seeking ways to diminish Egypt's dependency on foreign oil imports, we had to look for the obvious resources to exploit. Oil shale is one of Egypt's resources that are left abandoned and not used. This project is aiming at introducing both experimental analysis for oil shale in Egypt and the best production technique for it. This study is about experimentally analyzing different samples of potential oil shale fields in Egypt. Samples that are analyzed in this project are from two locations in Egypt: Quseir-Safaga and Abu-Tartur Western Desert, and they are compared to one of the best oil shale fields in the world, which is from Green River Formation Colorado. The experiments were done using AUC lab retort to experimentally determine the critical temperature that will lead to the maximum production using sudden and gradual change in temperatures, which turned out to be sudden change at $500^{\circ} \mathrm{C}$. Thereafter, the degree of API gravity was calculated for each run. Then the oil samples were determined for impurities and liquid chromatography results in the Egyptian Petroleum Research Institute. Part two of the study plan has been included to determine the ultimate ways of producing efficiently, ecologically and economically.
\end{abstract}

\section{Keywords}

Oil Shale, Retort Method, Critical Temperature, Oil Composition

\section{Introduction}

Oil shale is diverse fine-grained sedimentary rock, which contains refractory organic material that can be refined

How to cite this paper: Moustafa, E.-A., Noah, A., Salem, A., Nehad, A., Amir, M., Nosr, M., Awad, R., Gomaa, M. and Moussa, M. (2014) Evaluation and Analysis of Oil Shale in Quseir-Safaga and Abu-Tartur Western Desert, Egypt. Journal of Surface Engineered Materials and Advanced Technology, 4, 53-65. http://dx.doi.org/10.4236/jsemat.2014.42009 
into substantial amounts of oil and combustible gas. Soluble bitumen fraction constitutes about $20 \%$ of this organic material, whereas the remainder exists as an insoluble kerogen. Oil shale can be mined and processed to generate oil similar to oil pumped from conventional oil wells; however, extracting oil from oil shale is more complex than conventional oil recovery and currently it is more expensive. The oil substances in oil shale are solid and cannot be pumped directly out of the ground. The oil shale must first be mined and then heated to a high temperature (a process called retorting); the resultant liquid must then be separated and collected. This process of heating the shale experience is called pyrolysis, where oil shale is heated at high temperatures till it gets separated. Upon cooling the vapor, the liquid shale oil is separated from the combustible oil. An alternative but currently experimental process referred to as in situ retorting involves heating the oil shale while it is still underground, and then pumping the resulting liquid to the surface. Since 2008, Egypt's oil consumption has outperformed production. As the consumption increased, Egypt's imports both crude oil and refined petroleum products have increased making up the output decrease and increasing demand. Oil imports are estimated, from the central Bank of Egypt's data of the fiscal year 2009/2010, to 177,200 bbl/day (2009 est.) at a peak 9.8 Billion US dollars on 2009 and 5 billion dollars on 2010. Figure 1 demonstrates the production of oil vs the consumption of it done by the EIA (Energy Information Analysis) by Sabagh, S.M. et al. (2012) [1].

Egypt is not energy independent, and it has to import oil to meet its demands because of its limited conventional oil resources. On the other hand, in Egypt, oil shale is rich and yet it has not been used. Putting into consideration the rising prices of oil which is an economic burden, oil shale will be the future for Egypt to pave the way into its energy independency.

\section{Objectives of Subject}

The main objective of subject is to make use of the abundant oil shale in Egypt that represents a promising unconventional oil resource that could shift the Egyptian oil production upward and therefore reducing the dependency of Egypt on foreign oil. It has been worked on this objective through these steps:

1) Characterization of oil shale samples obtained from El-Nakheil phosphate mine in Quseir area from the point of optimum temperature and time needed for retorting,

2) Comparing the results obtained from the study of Quseir oil shale by others obtained from Colorado oil shale,

3) Analyzing the oil obtained from retorting in terms of API gravity and impurities content in order to know oil grade and therefore its price, and

4) Presenting an economic study of the various techniques of producing oil from oil shale and choosing the best one.

The chemical composition of the dead organisms is a mixture of carbohydrates, fats, oils waxes, proteins and lignin, which is present in the case of higher order plants and is responsible for the mechanical structure and rigidity of these plants. Those chemicals are then transformed to a new family of solid substances called Kerogen

Total Oil Production and Consumption in Egypt. 1990-2011

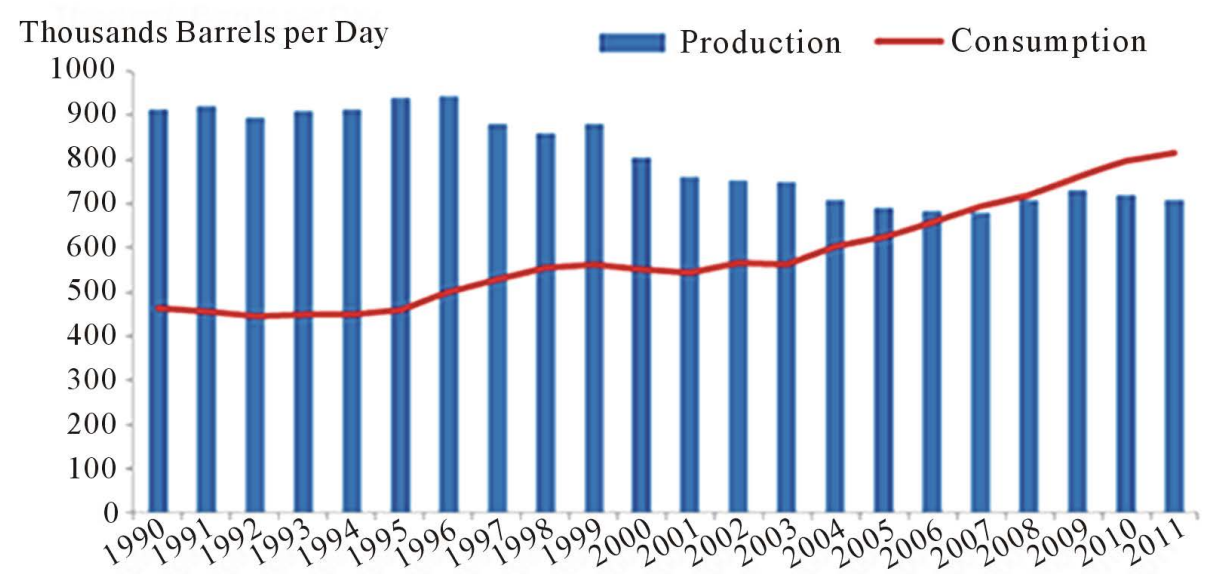

Figure 1. Egypt oil production versus consumption from 1990 to 2011 by El-Sabagh, et al. $[1]$. 
which are characterized by their brown or black color and their insolubility in ordinary organic solvents because of its huge molecular weight that is more than 1000 Daltons by Demirbas (2009) [2].

Kerogen is considered the half way in the petroleum production process. As Kerogen is buried deeper inside the earth, it becomes exposed to high temperature and pressure causing "cooking" to occur. The slow cooking of Kerogen for millions of years causes its molecules to decompose into small chain hydrocarbons called crude oil and natural gas by Darwish (1984) [3].

Petroleum fluids consist mainly of carbon, hydrogen and small amounts of oxygen, nitrogen and sulfur. The fractions of these components vary greatly from one deposit to another. Physical characteristics of crudes also vary according to their composition. They range from black, high viscous fluid to light colored, low viscous fluids. The density of oil is less than that of water so it's found above the underground water in any conventional reservoir by Al-Wakeel, and El-Adly (2005) [4].

Oil shale represents a large and mostly untapped hydrocarbon resource. Like tar sand and coal, oil shale is considered unconventional because oil cannot be produced directly from the resources by sinking a well and pumping. Oil has to be produced thermally from the shale. The term "oil shale" does not have a definite geological definition nor a specific chemical formula, but is a general term used for usually fine-grained sedimentary rocks containing organic matter that yield significant amounts of oil upon pyrolysis. This organic material contained in the shale is called "kerogen", a solid material intimately bound within the mineral matrix by AbdeIrahman, and Aly (1994) [5].

Oil shale was deposited in a wide variety of environments, including fresh water to saline ponds and lakes, epicontinental marine basins, and related sub-tidal shelves as well as shallow ponds or lakes associated with coal forming. This gives an explanation to the wide range of organic and mineral compositions by Energy Information Administration (EIA) (2012) [6].

Raw oil shale has high compressive strengths both perpendicular and parallel to the bedding plane. After heating, the inorganic matrices of oil shale retain high compressive strength in both perpendicular and parallel planes. This indicates that a high degree of inorganic cementation exists between the mineral particles comprising each lamina and between adjacent laminae (a thin layer, plate, or scale of sedimentary rock). With an increase of organic matter of oil shale, the compressive strength of the respective organic-free mineral matrices decreases, and it becomes very low in that rich oil shale by Abdelrahman, and Aly (1994) [5].

Measurements of thermal conductivity of oil shale show that blocks of oil shale are anisotropic about the bedding plane and thermal conductivity as a function of temperature, oil shale assay and direction of heat flow, parallel to the bedding plane (parallel to the earth's surface for a flat oil shale bed), was slightly higher than the thermal conductivity perpendicular to the bedding plane. As layers of sedimentary material were deposited to form the oil shale bed over geological time, the resulting strata have a higher resistance to heat flow perpendicular to the strata than parallel to the strata by Demirbas (2009) [2].

The thermal conductivity of oil shale is, in general, only weakly dependent on the temperature. However, extreme caution needs to be exercised in the interpretation of results at temperatures close to the decomposition temperature of the shale organic matter. This is due to the fact that the kerogen decomposition reaction (pyrolysis reaction) is endothermic in nature, and as such the temperature transients can be confound between the true rate of heat conduction and the rate of heat reaction by Abdelrahman, and Khaled (1988) [7].

In the process of the production of shale oil from oil shale, both the chemical and physical properties of oil shale play important roles. The low porosity, low permeability, and high mechanical strength of the oil shale rock matrix make the extraction process less efficient by making the mass transport of reactants and products much harder as well as reduce the process efficiency by Denning (2012) [8].

These properties are strongly affected by temperature as the increase in the temperature results in loss of strength and decrease in Young's modulus.

The permeability of raw oil shale is essentially zero because the pores are filled with a non-displaceable organic material. In general, oil shale constitutes a highly impervious system. Thus, one of the major challenges for any in situ retorting project is in the creation of a suitable degree of permeability in the formation by Sykes, and Snowdon (2002)[9].

Therefore, the oil shale porosity increases as the pyrolysis reaction proceeds. The increase in porosity constitutes essentially the combined spaces represented by the loss of the organic matter and the decomposition of the mineral carbonates. Cracking of particles also occurs, due to the devolatilization (the removal of volatile material) of organic matter and the decomposition of organic matter that increase the internal vapor pressure of large 
non-permeable pores to an extent that the mechanical strength of the particle can no longer contain. Liberation of carbon dioxide from mineral carbonate decomposition also contributes to the pressure buildup in the oil shale pores. Table 1 shows both the porosity and the permeability of oil shale before and after the treatment processes by Chillingarian and Yen (1978) [10].

\subsection{Oil Shale Grade}

The grade of oil shale has been determined by different methods. For example, the heating value is useful for determining the quality of an oil shale that is burned directly in a power plant to produce electricity. The heating value of the oil shale is a useful and a fundamental property of the rock, yet it cannot provide information on the amounts of shale oil or combustible gas that would be yielded by retorting (Altun, et al. (2006)) [11].

The grade of the oil shale can be determined by measuring the yield of distillable oil produced from a shale sample in a laboratory retort. This is the most common type used in evaluating the oil shale source. The method used is called "Modified Fischer assay".

\subsubsection{Modified Fischer Assay}

It consists of heating a $100-\mathrm{g}$ sample crushed to $(2.38 \mathrm{~mm})$ screen in a small aluminum retort at $500^{\circ} \mathrm{C}\left(930^{\circ} \mathrm{F}\right)$ at a rate of $12^{\circ} \mathrm{C}\left(21.6^{\circ} \mathrm{F}\right)$ per minute and held at that temperature for 40 minutes. The distilled vapors of oil, gas and water are passed through a condenser cooled with ice water and then into graduated centrifuge tube. The oil and water are separated by centrifuging. The quantities reported are the weight percentages of shale oil (and its specific gravity), water, shale residue, and (by difference) gas plus losses. The Fischer assay method doesn't measure the total energy content of an oil shale sample because the gases, which include methane, ethane, propane, butane, hydrogen, hydrogen sulfide, and carbon dioxide, can have significant energy content, but are not individually specified.

Other retorting methods, such as the Tosco II process, are known to yield in excess of $100 \%$ of that reported by Fischer assay. In fact, some methods of retorting can increase oil yields of some oil shale by as much three to four times that obtained by the Fischer assay method.

\subsubsection{The Rock-Eval Technology Test}

Behar, et al. (2001) [12], another method for characterizing the organic richness of oil shale is a pyrolysis test developed by the InstitutFrancais du Petrole for analyzing source rocks. The Rock-Eval technology test heats $(50-100 \mathrm{mg}$ ) sample through several temperature stages to determine the amounts of hydrocarbon and carbon dioxide generated by Vandenbroucke, and Largeau (2007) [13]. The results can be interpreted for kerogen type and potential for oil and gas generation. This method is faster than Fischer assay and requires less sample material.

Table 1. Porosity and permeability of oil shale before and after treatment processes.

\begin{tabular}{|c|c|c|c|c|c|}
\hline \multicolumn{6}{|c|}{ Porosity and Permeability of Raw and Treated Oil Shale } \\
\hline \multirow{2}{*}{ Fischer Assay } & \multicolumn{2}{|c|}{ Porosity } & \multirow{2}{*}{ Plane } & \multicolumn{2}{|c|}{ Permeability } \\
\hline & Raw & Heated to $815^{\circ} \mathrm{C}$ & & Raw & Heated to $815^{\circ} \mathrm{C}$ \\
\hline \multirow{2}{*}{$1.0^{1}$} & \multirow{2}{*}{$9.0^{2}$} & \multirow{2}{*}{11.9} & $\mathrm{~A}^{3}$ & \multirow{2}{*}{---} & $0.36^{4}$ \\
\hline & & & $\mathrm{B}$ & & 0.56 \\
\hline \multirow{2}{*}{6.5} & \multirow{2}{*}{5.5} & \multirow{2}{*}{12.5} & A & \multirow{2}{*}{---} & 0.21 \\
\hline & & & B & & 0.65 \\
\hline \multirow{2}{*}{13.5} & \multirow{2}{*}{0.5} & \multirow{2}{*}{16.4} & A & \multirow{2}{*}{---} & 4.53 \\
\hline & & & $\mathrm{B}$ & & 8.02 \\
\hline \multirow{2}{*}{20.0} & \multirow{2}{*}{$<0.03$} & \multirow{2}{*}{25.0} & A & \multirow{2}{*}{--- } & \multirow[t]{2}{*}{---} \\
\hline & & & $\mathrm{B}$ & & \\
\hline \multirow{2}{*}{40.0} & \multirow{2}{*}{$<0.03$} & \multirow{2}{*}{50.0} & A & \multirow{2}{*}{--- } & \multirow[t]{2}{*}{--- } \\
\hline & & & B & & \\
\hline
\end{tabular}

Source: Chillingarian and Yen (1978); [10], ${ }^{1}$ Fischer assay in gallons per ton, ${ }^{2}$ Numbers in percentages of the initial bulk volume, porosity was taken as an isotropic property, that is, property that is independent of measurement direction, ${ }^{3}$ Plane A is perpendicular to the bedding plane; plane B is parallel to the bedding plane, ${ }^{4}$ Units in millidarcy. 
During retorting, kerogen decomposes into the three organic fractions: Shale Oil, Gas and Carbonaceous Residue. Oil shale decomposition begins at relatively low retort temperatures $\left(300^{\circ} \mathrm{C}\right.$ or $\left.572^{\circ} \mathrm{F}\right)$ but proceeds more rapidly and more completely at higher temperatures. The highest rate of kerogen decomposition occurs at retort temperatures of $\left(480^{\circ} \mathrm{C}-520^{\circ} \mathrm{C}\right)$ or $\left(895^{\circ} \mathrm{F}-970^{\circ} \mathrm{F}\right)$. In general, the shale oil yield decreases, the gas yield increases, and the aromaticity of the oil increases with increasing decomposition temperature. However, there is an upper limit on optimal retorting temperature, as the mineral content of the shale may decompose if the temperature is too high.

The processes for producing oil from oil shale involve heating (retorting) the shale to convert the organic kerogen to a raw shale oil. The amount and composition of generated hydrocarbons depend on the heating conditions, the rate of temperature increase, the duration of exposure to heat and the composition of gases present as the kerogen breaks down.

In United States of America, It is estimated to have nearly $74 \%$ of the world's potentially recoverable oil shale. Green river formation is the richest most easily recoverable basin in the world. It is estimated to have 301,556 million tons of oil shale reserves which can count for 2085.3 billion barrels.

Oil shale in Egypt was discovered during the 1940's as a result of self-igniting while phosphate mining was taking place. The phosphate beds in question lie adjacent to the Red Sea in the Safaga, Quseir area of the Eastern Desert. Oil shale resources mainly found in Egypt in Quseir-Safaga region(alongred sea coast), the IDFU region (along the Nile valley) and Kharga, Dakhla region in the western desert (Abu Tartur), Abu-zinema in the west Sinai and the area of Al-Maghara coal mine north Sinai.

In Quseir-Safaga area (Red Sea) has a reserve of 5 billion barrel of oil in place, in the area of Abu Tartour 1.2 billion barrel of oil in place, in Gabel Duwi has 4.8 billion barrel of oil in place, Abu Sheyala has 1 billion barrel oil in place, West Youns area has 2 billion barrel oil in place, Zog El Behar has 2.5 billion barrel oil in place therefore total discovered reserve in Egypt is nearly 16.5 billion barrel of shale oil in place (see Figure 2).

Oil shale Production Techniques included that two production techniques of oil shale; either through mining; bringing the rock up at the surface where it is processed or $I n$-situ, where the heat is sent or placed down at the shale layers and the shale is processed with no need for mining.

The whole process of mining and retorting consumes large volumes of water, creates large piles of used shale and extracts only the richest portion of oil shale formation as approximately one third of the oil shale is left behindin pillars or unmined areas. Each barrel of oil shale, according to "Dirty Fuel: Oil Shale" article in the Sierra Club, produces by conventional mining consumes between 2.1 and 5.2 barrels of water; which is already scarce in the region. Also, mining contributes to global warming immensely; the United States has conducted a research

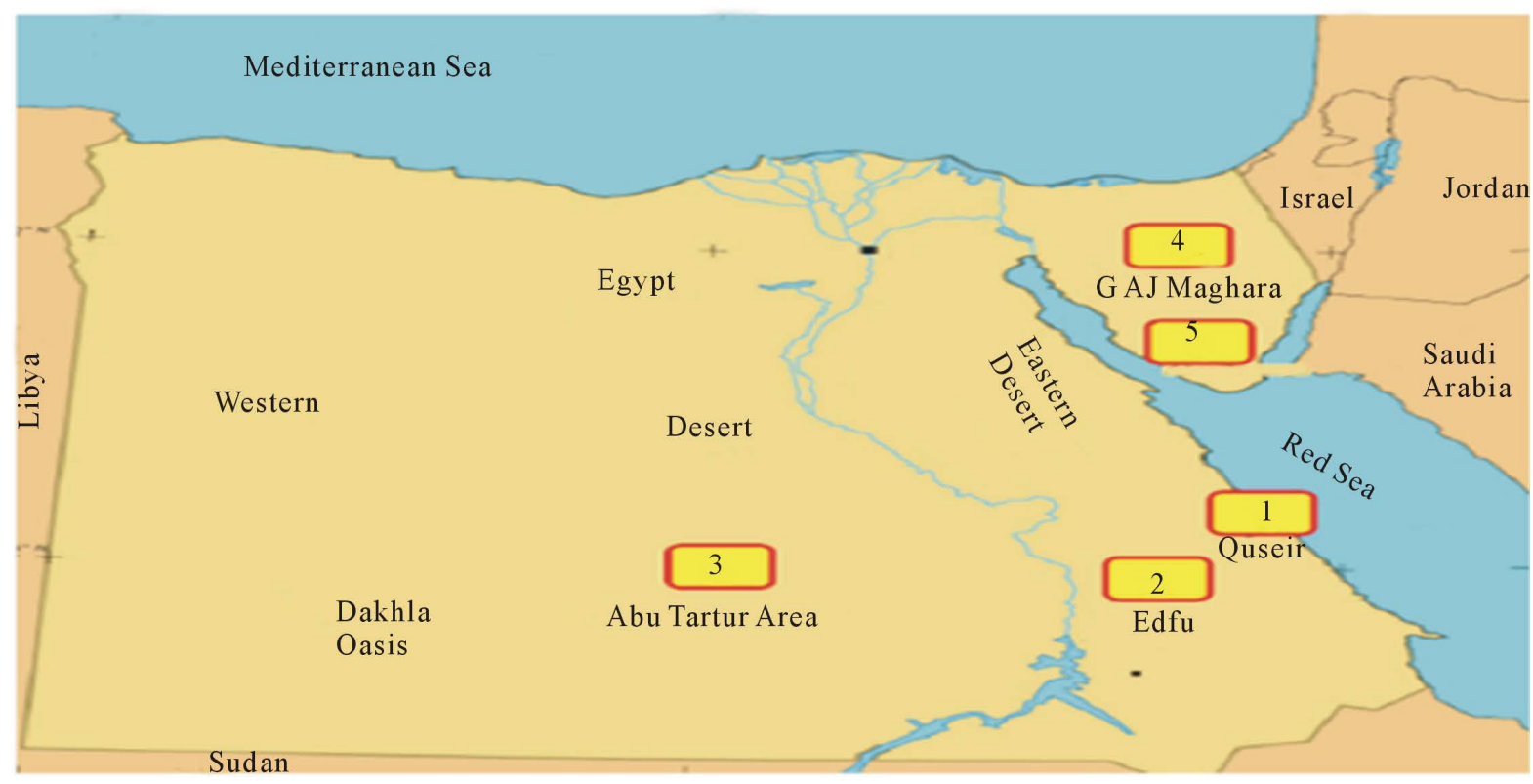

Figure 2. Oil Shale at different places in Egypt such as in the Quseir Area-Safaga of the Eastern Desert, Abu-Zinema of the west Sinai and Abu-Tartur of the western desert. 
that says if it is were to produce 3 million barrels per day of oil shale from mining, that will contribute in producing 350 million tons of carbon dioxide annually, which is $5 \%$ of the U.S. global warming current pollution (Dirty Fuel: Oil Shale). Impacts on wildlife from oil shale mining projects could occur in a number of ways, including habitat loss, alteration, or fragmentation; disturbance and displacement; mortality; and increase in human access.

\subsection{In-Situ Production Techniques}

In-situ production aims at increasing the recoverability of oil shale and eliminating the use of huge amount of water. A lot of techniques were introduced before and they were developed later to come up with better techniques in terms of recoverability and less environmental impacts. Two of the used in-situ techniques in the past were the true $i n$-situ and modified in-situ that involved igniting the formation; they are as follows:

TRUE IN-SITU: This involves mining the shale. The target deposit is fractured, air is injected, the deposit is ignited to heat the formation, and resulting shale oil is moved through the natural or man-made fractures to production wells that transport it to the surface. In true in-situ processes, difficulties in controlling the flame front and the flow of pyrolysis oil (also known as bio-crude or bio-oil) which can limit the ultimate oil recovery, that is pyrolytic oil (or bio-oil) is a normally contains too high levels of oxygen to be a hydrocarbon and leaving portions of the deposit unheated and portions of the pyrolyze oil unrecovered.

MODIFIED IN-SITU: This attempt to improve performance by exposing more of the target deposit to the heat source and by improving the flow of gases and liquid fluids through the rock formation, and increasing the volumes and quality of the oil produced. Modified in-situ involves mining beneath the target oil shale deposit prior to heating. It also requires drilling and fracturing the target deposit above the mined area to create void space. This voidspace is needed to allow heated air, produced gases, and pyrolyze shale oil to flow towards production wells. The shale is heated by igniting the top of the target deposit. Condensed shale oil that is pyrolyze ahead of the flame is recovered from beneath the heated zone and pumped to the surface.

\section{Experimental Work of This Study}

The experimental work in this study was divided into four sections. The first section deals with the thermal decomposition of the organic matter inside the Oil Shale to produce oil. The remaining sections are all about characteristics of the obtained oil in terms of degree API gravity, liquid chromatography and sulfur content. Experimental work was done in the rock and fluid laboratory in the American University in Cairo and other laboratories in the Egyptian Petroleum Research Institute in Egypt.

Random oil shale samples are obtained from El-Nakheil phosphate mine in Qusier area, which is located in the Eastern Desert of Egypt near the red sea. Other oil shale samples are obtained from Abu Tartur area in the Western Desert of Egypt. We also managed to get some oil shale samples from Colorado.

Qusier oil shale is characterized by its dark grey to black color and the flaky arrangement of its layers. Abu Tartur oil shale is characterized by its light grey color, smooth surface and its easiness to be crushed. Colorado oil shale is light brown in color and is the hardest rock to be crushed among the others (see Figure 3).

\subsection{Procedure}

\subsubsection{Retorting}

The oil shale samples were, firstly, reduced in size by manual crushing. Crushing is done because oil shale is impermeable so it needs to be crushed to allow the produced fluids to move out of the bulk (see Figure 4). Oil shale samples were treated thermally by retorting in the laboratory retort.

1) The retort cell was charged by 100 g-ground oil shale sample.

2) The retort cell is closed by a screwed lid and placed in its chamber where heat starts.

3) Water droplets begin first to appear followed by gases and then by oil.

4) Heating continued till there were no liquid or gases coming out of the retort cell.

5) The average amount of oil and water was calculated and recorded.

6) The weight of the sample was recorded after retorting.

The density of the produced oil was determined by knowing its mass and volume and then used to calculate its degree API gravity. 


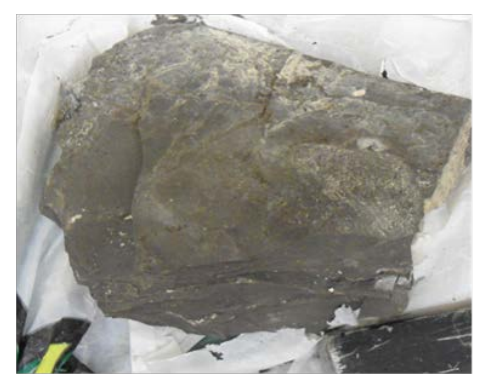

(a)

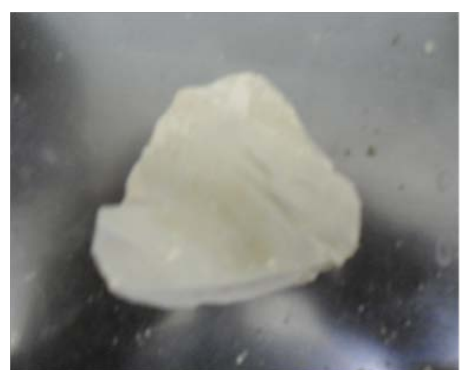

(b)

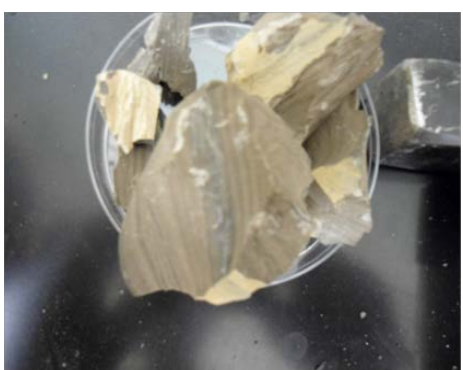

(c)

Figure 3. Oil Shale samples from (a) Quseir; (b) Abu Tartour; (c) Colorado regions.
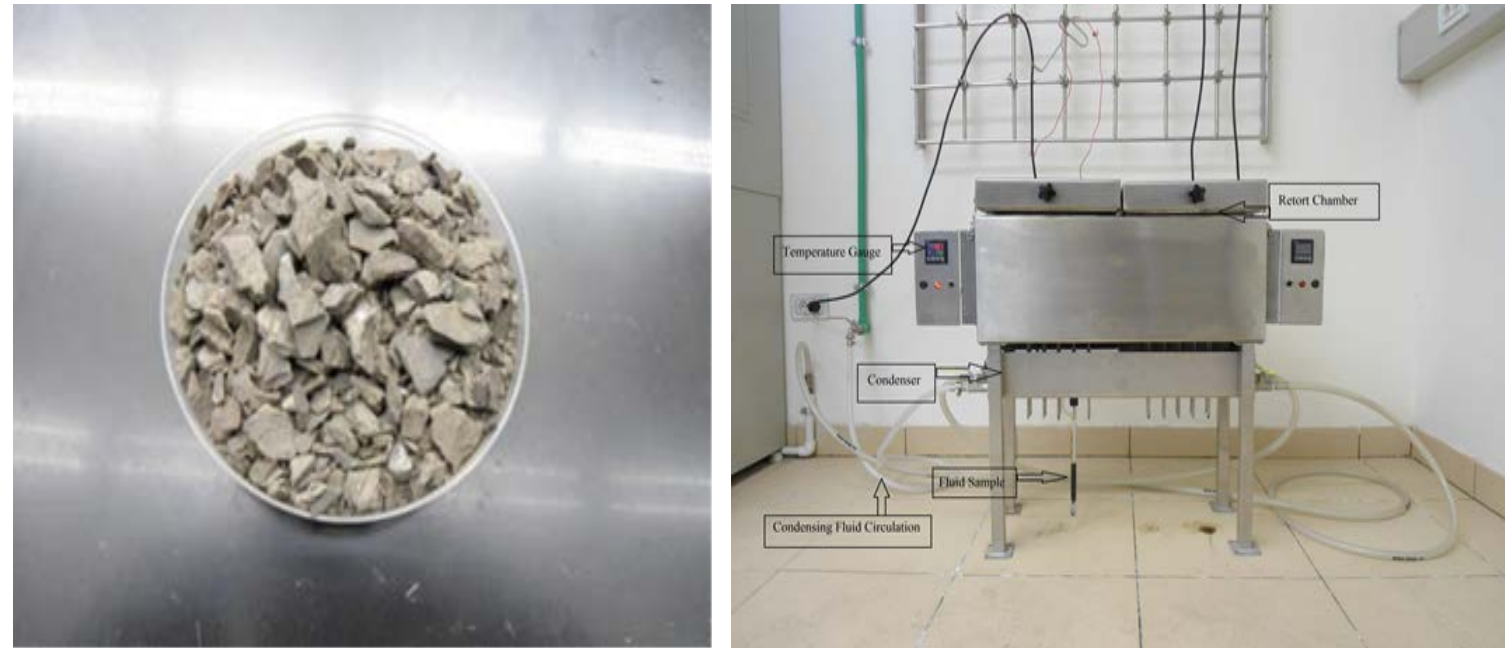

Figure 4. Crushed sample for oil shale and put in the retort at different temperatures.

\subsubsection{Liquid Chromatography}

Quantitation of Individual organic compounds in shale oil Chromatography may be preparative or analytical. The purpose of preparative chromatography is to separate the components of a mixture for more advanced use (and is thus a form of purification). Analytical chromatography is done normally with smaller amounts of material and is for measuring the relative proportions of analyses in a mixture.

1) Liquid Chromatography-Mass Spectrometry (LC-MS), which is a chemistry technique that combines the physical separation capabilities of LC or HPLC with the mass analysis capabilities of mass spectrometry, is a powerful technique used for many applications, which has very high sensitivity and selectivity. Generally its application is oriented towards the general detection and potential identification of chemicals in the presence of other chemicals (A complex mixture like shale oil) by Tissot, and Welte (1984) [14].

2) High-Performance Liquid Chromatography is basically a highly improved form of column chromatography. Instead of a solvent being allowed to drip through a column under gravity, it is forced through under high pressures of up to 400 atmospheres. It also allows you to use a very much smaller particle size forthe column packing material (for example: silica particles), which gives a much greater surface area for interactions between the stationary phase and the molecules flowing past it. This allows a much better separation of the components of the mixture which the constituents of the shale oil.

\subsubsection{Sulfur Content in Qusier Shale Oil Sample (General Bomb Method)}

By comparison, a typical $35^{\circ}$ API gravity crude oil may be composed of up to $50 \%$ of gasoline and middle-distillate range hydrocarbons. West Texas Intermediate crude (benchmark crude for trade in the commodity future market) has $0.3 \%$ sulfur by weight. This means that the sulfur content in the oil must be known in order to compute the degree of API gravity and then the price of the oil depending on it. The experiment is all about oxidizing the liquid sample as the "bomb" in which the experiment is carried out is under high pressure by Darwish (1984) [3]. 


\subsubsection{Reagents}

1) Purity of reagents: the reagents grade, unless otherwise indicated, follows the specifications of the "Committee on Analytical Reagents of the American Chemical Society". For a reagent to be used, it should be of a high purity so it won't lessen the accuracy of the determination,

2) Purity of Water: Unless otherwise indicated, mean distilled water or water of equal purity,

3) Barium Chloride Solution ( $85 \mathrm{~g} /$ liter $) \rightarrow$ Dissolve $100 \mathrm{~g}$ of Barium Chloride Dehydrate $\left(\mathrm{BaCl}_{2} \cdot 2 \mathrm{H}_{2} \mathrm{O}\right)$ in distilled water and dilute to 1 liter,

4) Bromine Water (saturated),

5) Concentrated of Hydrochloric acid (HCL) $\sim \gamma=1.19$,

6) Oxygen and sulfur compounds (available at pressure $40 \mathrm{~atm}$ ),

7) Sodium Carbonate Solution ( $50 \mathrm{~g} /$ liter $) \rightarrow$ Dissolve $135 \mathrm{~g}$ of sodium Carbonate Deca-hydrate $\left(\mathrm{Na}_{2} \mathrm{CO}_{3} \cdot 10 \mathrm{H}_{2} \mathrm{O}\right)$ in distilled water and dilute to 1 liter,

8) White Oil, USP, or Liquid Paraffin, BP by Darwish (1984) [3].

\subsubsection{Procedure for Measure of Sulfur Content}

First of all, the bomb should be cleaned for sulfur determination by periodic polishing that can remove any film that might be formed by the sulfur content of the previous test carried out on the same bomb. Introduce into the sample cub a quantity of the sample and white oil, and then stir the sample with quartz rod and allow the rod to remain in the sample cup during the combustion.

\subsubsection{Determination of Sulfur Content}

Evaporate the combined washings to $200 \mathrm{ml}$ on a hot plate or any other source of heat. Adjust the heat so you can maintain slow boiling, and add 10 of $\mathrm{BaCl}_{2}$ to the solution. Stir the solution during the addition and for two more minutes. Cover the beaker and continue boiling slowly until the solution has evaporated to $75 \mathrm{ml}$. Then remove the beaker and allow it to cool before filtering. Then wash the precipitates until they are free from chloride. Dry both the paper and the precipitates after transferring them into crucible at a low heat. A satisfactory means of drying, charring and igniting the paper and precipitates are to place the crucible containing the wet filter paper in a cold electric muffle furnace and to turn on the current. Such processes occur on a desired rate by Darwish (1984) [3].

\subsection{Results and Discussion}

There are eight different runs it's included that calculate of density of product from oil shale and then, calculate the ${ }^{\circ} \mathrm{API}$ gravity for oil. In addition to determine the oil volume at different time dependent mainly on temperature with how much oil product from oil shale and versus time. Table 2 show that the results for experimental studies at different runs on Quseir and Colorado Oil shale samples. These results represent weight of sample before and after extracted process and maximum temperature so extracted all volume of oil into sample.

In addition to, focus for the droplet formation water and oil at different time. Finally, total oil and formation water volumes determined and calculated specific gravity and degree of API gravity. Table 3 shows that the volume of oil and formation water from oil shale for eight runs which it's are from Quseir and Colorado. After conducting the previous experiments and analyzing the obtained results we reached the following recapitulations:

1) The critical temperature that yields the maximum volume of oil is $\mathrm{T}=500^{\circ} \mathrm{C}$,

2) The maximum volume of oil is 15.7 milliliters/100 grams, which is equivalent to 157 Liters/Ton,

3) The optimum time needed to reach maximum oil production is approximately 48 minutes for 100 grams of oil shale rock sample,

4) The higher the temperature used for retorting, the heavier the oil obtained because of the vaporization of its light contents,

5) The results of gradual increasing temperature experiment showed that the maximum volume of oil obtained is less than that obtained from the sudden increase of temperature $\left(\mathrm{T}=500^{\circ} \mathrm{C}\right)$, and it took more time to reach it; however, it showed better degree API value,

6) After measuring the weight of the sample before and after the experiment we concluded that there was a weight loss by about $25 \%$ which is due to:

a) Decomposition of Kerogen,

b) Loss of water content in the sample, and 
Table 2. Results for experimental studies for different runs on quseir and colorado oil shale samples.

\begin{tabular}{|c|c|c|c|c|c|c|c|c|}
\hline Oil shale Sample & & & & & & & & \\
\hline \multicolumn{9}{|c|}{ Colorado-1 Colorado-2 } \\
\hline Weight of sample, gm & 100 & 100 & 100 & 100 & 100 & 100 & 100 & 100 \\
\hline Max. Temp. used, ${ }^{\circ} \mathrm{C}$ & 450 & 500 & 550 & 490 & 510 & $400-450-500$ & 500 & 550 \\
\hline $\begin{array}{l}\text { First droplet of water at } \\
\text { Time, min. @ T, }{ }^{\circ} \mathrm{C}\end{array}$ & $\begin{array}{c}8.83 \mathrm{~min} \\
385^{\circ} \mathrm{C}\end{array}$ & $\begin{array}{l}5.62 \mathrm{~min} \\
374^{\circ} \mathrm{C}\end{array}$ & $\begin{array}{l}3.58 \mathrm{~min} \\
230^{\circ} \mathrm{C}\end{array}$ & $\begin{array}{c}9.25 \mathrm{~min} \\
380^{\circ} \mathrm{C}\end{array}$ & $\begin{array}{l}8.57 \mathrm{~min} \\
372^{\circ} \mathrm{C}\end{array}$ & $\begin{array}{c}7.50 \mathrm{~min} . \\
335^{\circ} \mathrm{C}\end{array}$ & $\begin{array}{c}6.47 \mathrm{~min} \\
310^{\circ} \mathrm{C}\end{array}$ & $\begin{array}{c}9.83 \mathrm{~min} \\
354^{\circ} \mathrm{C}\end{array}$ \\
\hline $\begin{array}{c}\text { First droplet of oil at Time, } \\
\text { @ T, }{ }^{\circ} \mathrm{C}\end{array}$ & $\begin{array}{c}15.67 \mathrm{~min} . \\
428^{\circ} \mathrm{C}\end{array}$ & $\begin{array}{c}11.25 \mathrm{~min} . \\
465^{\circ} \mathrm{C}\end{array}$ & $\begin{array}{c}14 . .80 \mathrm{~min} . \\
463^{\circ} \mathrm{C}\end{array}$ & $\begin{array}{l}14.83 \mathrm{~min} \\
472^{\circ} \mathrm{C}\end{array}$ & $\begin{array}{c}13.43 \mathrm{~min} . \\
481^{\circ} \mathrm{C}\end{array}$ & $\begin{array}{c}17.33 \mathrm{~min} . \\
400^{\circ} \mathrm{C}\end{array}$ & $\begin{array}{l}21.50 \mathrm{~min} \\
500^{\circ} \mathrm{C}\end{array}$ & $\begin{array}{l}19.22 \mathrm{~min} . \\
530^{\circ} \mathrm{C}\end{array}$ \\
\hline Retort Temp. at Time, & $\begin{array}{l}19.0 \mathrm{~min} \\
450^{\circ} \mathrm{C}\end{array}$ & $\begin{array}{l}18.00 \mathrm{~min} \\
500^{\circ} \mathrm{C}\end{array}$ & $\begin{array}{l}22.00 \mathrm{~min} \\
550^{\circ} \mathrm{C}\end{array}$ & $\begin{array}{l}22.33 \mathrm{~min} \\
490^{\circ} \mathrm{C}\end{array}$ & $\begin{array}{l}19.00 \mathrm{~min} . \\
510^{\circ} \mathrm{C}\end{array}$ & $\begin{array}{l}16.83 \mathrm{~min} . \\
400^{\circ} \mathrm{C}\end{array}$ & $\begin{array}{l}19.00 \mathrm{~min} \\
500^{\circ} \mathrm{C}\end{array}$ & $\begin{array}{l}22.83 \mathrm{~min} . \\
550^{\circ} \mathrm{C}\end{array}$ \\
\hline Max. Volume of Oil at Time, & 14.3 & 15.7 & 15.2 & 14.8 & 15.5 & 13.9 & 4.4 & 2.65 \\
\hline $\mathrm{cc}$ & $64 \mathrm{~min}$. & $48 \mathrm{~min}$. & $47 \mathrm{~min}$. & $52 \mathrm{~min}$. & $49 \mathrm{~min}$. & $92 \mathrm{~min}$. & $44 \mathrm{~min}$. & $38 \mathrm{~min}$. \\
\hline Mass of Oil, gm & 12.2870 & 13.6699 & 13.2346 & 12.7990 & 11.3848 & 11.4619 & 3.7115 & 2.2133 \\
\hline Specific gravity, gm/cc & 0.8592 & 0.8707 & 0.8707 & 0.8648 & 0.7345 & 0.8596 & 0.8435 & 0.8352 \\
\hline${ }^{\circ}$ API Gravity & 33.19 & 31.00 & 28.96 & 32.10 & 30.50 & 33.11 & 36.25 & 37.92 \\
\hline $\begin{array}{l}\text { Mass of sample after } \\
\text { experiment, gm }\end{array}$ & 73.48 & 73.01 & 72.68 & 73.21 & 72.68 & 73.29 & 93.85 & 93.10 \\
\hline
\end{tabular}

Notes: Calculate API gravity $=\frac{141.5}{\delta_{o}}-131.5$, where $\rho_{o}=\frac{\text { Mass }}{\text { Volume }}, \delta_{o}=\frac{\rho_{\text {oil }}}{\rho_{\text {water }}}$.

Table 3. Volume of oil and Formation water extracted from oil shale samples collected from Quseir, Egypt and Colorado, USA.

\begin{tabular}{|c|c|c|c|c|c|c|c|c|c|c|c|c|c|c|c|c|}
\hline \multicolumn{17}{|c|}{ Oil shale samples from different Regions } \\
\hline \multirow{2}{*}{$\begin{array}{l}\text { Region } \\
\text { Time, }\end{array}$} & \multicolumn{2}{|c|}{ Quseir-1 } & \multicolumn{2}{|c|}{ Quseir-2 } & \multicolumn{2}{|c|}{ Quseir-3 } & \multicolumn{2}{|c|}{ Quseir-4 } & \multicolumn{2}{|c|}{ Quseir-5 } & \multicolumn{2}{|c|}{ Quseir-6 } & \multicolumn{2}{|c|}{ Colorado-1 } & \multicolumn{2}{|c|}{ Colorado-2 } \\
\hline & FW & Oil & FW & Oil & FW & Oil & FW & Oil & FW & Oil & FW & Oil & FW & Oil & FW & Oil \\
\hline min. & $c c$ & $c c$ & $c c$ & $c c$ & $c c$ & $c c$ & $c c$ & $c c$ & $c c$ & $c c$ & $c c$ & $c c$ & $c c$ & $c c$ & $c c$ & $c c$ \\
\hline 15 & 2.5 & 0.6 & 2.9 & 3.7 & 2.7 & 5.5 & 2.7 & 2.3 & 2.8 & 3.9 & 1.9 & 0.0 & 1.0 & 0.0 & 0.3 & 1.2 \\
\hline 20 & 2.9 & 1.8 & 3.5 & 8.3 & 3.0 & 9.8 & 3.0 & 3.4 & 3.6 & 5.2 & 2.5 & 1.4 & 1.4 & 0.4 & 0.3 & 1.6 \\
\hline 25 & 3.5 & 5.3 & 3.5 & 11.5 & 3.1 & 11.6 & 3.5 & 8.3 & 3.6 & 10.1 & 3.3 & 2.9 & 1.5 & 2.4 & 0.5 & 1.9 \\
\hline 30 & 3.5 & 9.3 & 3.5 & 13.2 & 3.2 & 12.2 & 3.7 & 11.5 & 3.6 & 13.6 & 3.5 & 4.7 & 1.7 & 2.9 & 0.5 & 2.6 \\
\hline 35 & 3.5 & 10.2 & 3.5 & 14.1 & 3.3 & 12.6 & 3.7 & 12.8 & 3.6 & 14.8 & 3.6 & 6.3 & 1.6 & 4.0 & 0.5 & 2.6 \\
\hline 40 & 3.5 & 11.7 & 3.5 & 14.4 & 3.4 & 12.9 & 3.9 & 13.7 & 3.6 & 15.2 & 3.6 & 8.9 & 1.6 & 4.4 & 0.5 & 2.65 \\
\hline 45 & 3.5 & 13.0 & 3.5 & 14.7 & 3.5 & 13.2 & 4.0 & 14.0 & 3.6 & 15.4 & 3.6 & 10.8 & 1.6 & 4.4 & 0.5 & 2.65 \\
\hline 50 & 3.5 & 13.6 & 3.5 & 14.8 & 3.7 & 13.3 & 4.0 & 14.2 & 3.6 & 15.5 & 3.6 & 12.2 & 1.6 & 4.4 & 0.5 & 2.65 \\
\hline 55 & 3.5 & 14.1 & 3.5 & 15.1 & 3.9 & 14.7 & 4.0 & 14.3 & 3.6 & 15.5 & 3.6 & 12.5 & 1.6 & 4.4 & 0.5 & 2.65 \\
\hline 60 & 3.5 & 14.2 & 3.5 & 15.7 & 4.0 & 15.2 & 4.0 & 14.3 & 3.6 & 15.5 & 3.6 & 12.5 & 1.6 & 4.4 & 0.5 & 2.65 \\
\hline 65 & 3.5 & 14.3 & 3.5 & 15.7 & 4.0 & 15.2 & 4.0 & 14.8 & 3.6 & 15.5 & 3.6 & 12.5 & 1.6 & 4.4 & 0.5 & 2.65 \\
\hline 70 & 3.5 & 14.3 & 3.5 & 15.7 & 4.0 & 15.2 & 4.0 & 14.8 & 3.6 & 15.5 & 3.6 & 12.5 & 1.6 & 4.4 & 0.5 & 2.65 \\
\hline 75 & 3.5 & 14.3 & 3.5 & 15.7 & 4.0 & 15.2 & 4.0 & 14.8 & 3.6 & 15.5 & 3.6 & 12.6 & 1.6 & 4.4 & 0.5 & 2.65 \\
\hline 80 & 3.5 & 14.3 & 3.5 & 15.7 & 4.0 & 15.2 & 4.0 & 14.8 & 3.6 & 15.5 & 3.6 & 12.9 & 1.6 & 4.4 & 0.5 & 2.65 \\
\hline 85 & 3.5 & 14.3 & 3.5 & 15.7 & 4.0 & 15.2 & 4.0 & 14.8 & 3.6 & 15.5 & 3.6 & 13.5 & 1.6 & 4.4 & 0.5 & 2.65 \\
\hline 90 & 3.5 & 14.3 & 3.5 & 15.7 & 4.0 & 15.2 & 4.0 & 14.8 & 3.6 & 15.5 & 3.6 & 13.9 & 1.6 & 4.4 & 0.5 & 2.65 \\
\hline 95 & 3.5 & 14.3 & 3.5 & 15.7 & 4.0 & 15.2 & 4.0 & 14.8 & 3.6 & 15.5 & 3.6 & 13.9 & 1.6 & 4.4 & 0.5 & 2.65 \\
\hline
\end{tabular}

c) Decomposition of inorganic materials in the rock when it is subjected to high temperature.

Figure 5 shows that the relationship between volumes of formation water extracted versus time for different 
shale oil samples.

In addition, Figure 6 shows that relationship between volumes of oil extracted versus time for different shale oil samples.

1) The liquid chromatography analysis of the oil obtained from Qusier oil shale showed that the major portion of its composition is heavy alkanes from Nonane to Hexa-n-decanes (53.6 wt\%, $62.2 \mathrm{~mol} \%)$, these alkanes are characterized by their high viscosity. They are used as a major part of diesel and aviation fuel. There is also a considerable amount of Alkanes from Hexadecane upward (35.2 wt\%, $21.87 \mathrm{~mol} \%$ ), which are considered the most important components of fuel oil and lubricating oil and they are also used as anti-corrosive agents,

2) The oil obtained can be classified as medium sour or heavy sour crude oil because of its degree API gravity that ranges from $28^{\circ}$ to $33^{\circ}$ and sulfur content of $3.36 \mathrm{wt} \%$,

3) The average price of the obtained oil is 94.88 dollars/barrel. This was obtained by correlation between Kuwait blend crude oil and Orient blend crude oil because the characteristics of crude oil fall between these two types of oil shale,

4) Oil obtained from Colorado oil shale showed similar compositions and characteristics to that obtained from Qusier but the amount of oil obtained was considerably small. The reasons of this small production might be the following points:

a) The sample rock that was obtained may be weathered,

b) We don't know the weather conditions that it was subjected to, and

c) Due to its hardness we could not crush it into small particles as Qusier sample, which affects productivity.

Table 4 shows that weight and mole percent for Qusier and Colorado shale oil samples components and included for chemical formula and molar mass.

\section{Conclusions}

After conducting the oil shale experiments on different samples (Qusier, Abu-Tartur and Colorado) we reached different results that show that Qusier is a commercial field for oil shale production. We have also found out that the critical temperature at which the sample produces its maximum oil volume is $500^{\circ} \mathrm{C}$. An aim in paper is finding an economic and ecological in-situ production technique that gives an output of heat content equivalent to the $500^{\circ} \mathrm{C}$. The proposed ideas are:

1) Hydrogen fuel cell design (SOFC)

2) Geothermal fuel cell design

3) Comparison between Shell's technique (Underground heaters ICP) and Exon-Mobil technique (Geothermal fuel cells)

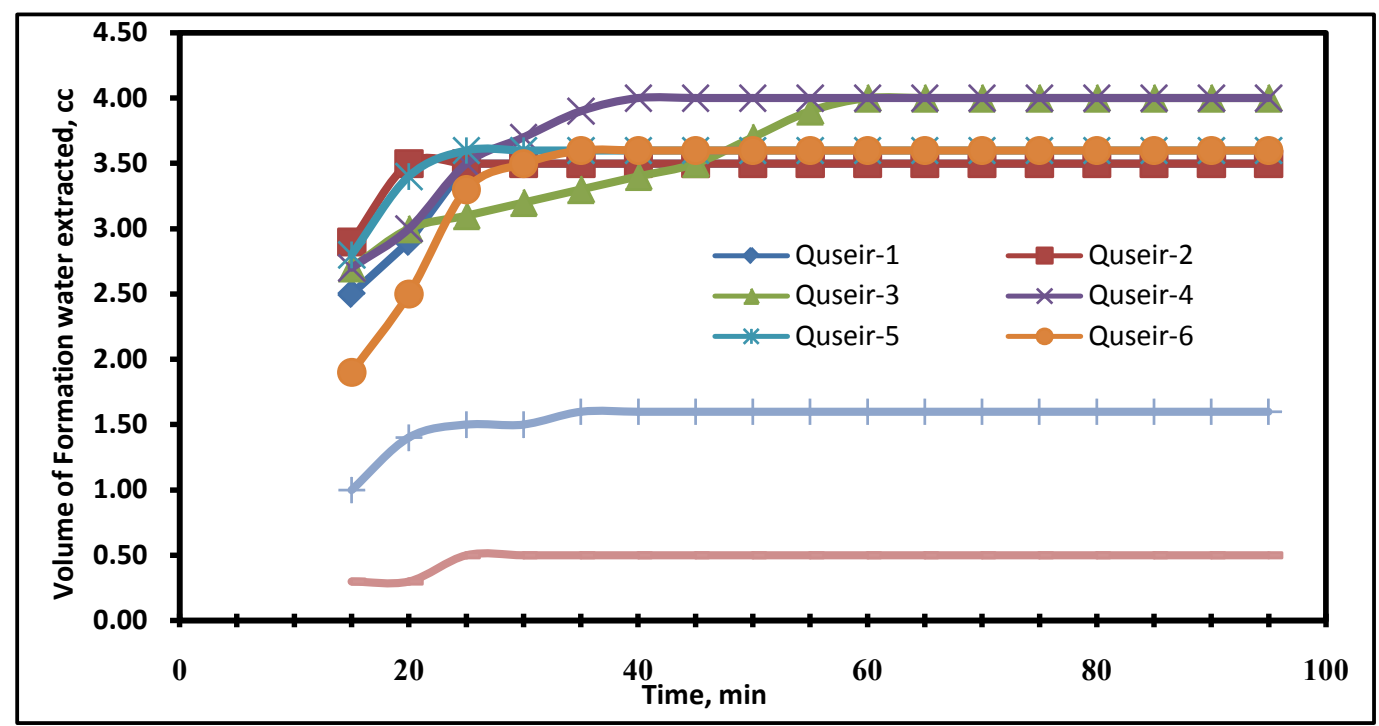

Figure 5. Relationship between volumes of formation water extracted versus time for different shale oil samples. 
We will base our comparison regarding these three techniques based on three main purposes:
a) Economics
b) Efficiency
c) Environmental impact

Table 4. Weight and mole percent for qusier and colorado shale oil samples components.

\begin{tabular}{|c|c|c|c|c|c|c|}
\hline \multirow{2}{*}{ Compounds } & \multirow{2}{*}{$\begin{array}{l}\text { Chemical } \\
\text { Formula }\end{array}$} & \multirow{2}{*}{$\begin{array}{c}\text { Molar mass } \\
\text { gm } / \text { mole }\end{array}$} & \multicolumn{2}{|c|}{ Qusier Shale Oil Sample } & \multicolumn{2}{|c|}{ Colorado Shale Oil Sample } \\
\hline & & & Wt.\% & Mol.\% & Wt.\% & Mol.\% \\
\hline Ethane & $\mathrm{C}_{2} \mathrm{H}_{6}$ & 30.07 & 0.000 & 0.000 & 0.000 & 0.000 \\
\hline Propane & $\mathrm{C}_{3} \mathrm{H}_{8}$ & 44.10 & 0.001 & 0.004 & 0.001 & 0.004 \\
\hline i-Butane & $\mathrm{i}-\mathrm{C}_{4} \mathrm{H}_{10}$ & 58.12 & 0.004 & 0.014 & 0.003 & 0.010 \\
\hline n-Butane & $\mathrm{n}-\mathrm{C}_{4} \mathrm{H}_{10}$ & 58.12 & 0.010 & 0.034 & 0.008 & 0.028 \\
\hline i-pentane & $\mathrm{i}-\mathrm{C}_{5} \mathrm{H}_{12}$ & 72.15 & 0.012 & 0.034 & 0.010 & 0.028 \\
\hline n-pentane & $\mathrm{n}-\mathrm{C}_{5} \mathrm{H}_{12}$ & 72.15 & 0.108 & 0.296 & 0.088 & 0.248 \\
\hline Hexanes & $\mathrm{C}_{6} \mathrm{H}_{14}$ & 86.18 & 0.949 & 2.173 & 0.754 & 1.775 \\
\hline Heptane & $\mathrm{C}_{7} \mathrm{H}_{16}$ & 100.20 & 1.688 & 3.326 & 1.339 & 2.710 \\
\hline Octane & $\mathrm{C}_{8} \mathrm{H}_{18}$ & 114.23 & 3.040 & 5.252 & 2.406 & 4.273 \\
\hline Nonane & $\mathrm{C}_{9} \mathrm{H}_{20}$ & 128.26 & 4.252 & 6.542 & 3.358 & 5.311 \\
\hline Decane & $\mathrm{C}_{10} \mathrm{H}_{22}$ & 142.28 & 5.130 & 7.115 & 4.046 & 5.770 \\
\hline Undecane & $\mathrm{C}_{11} \mathrm{H}_{24}$ & 156.31 & 6.246 & 8.386 & 5.908 & 8.154 \\
\hline Dodecane & $\mathrm{C}_{12} \mathrm{H}_{26}$ & 170.33 & 8.719 & 10.685 & 9.679 & 12.197 \\
\hline Tridecane & $\mathrm{C}_{13} \mathrm{H}_{28}$ & 184.36 & 9.456 & 10.663 & 9.130 & 10.586 \\
\hline Tetradecane & $\mathrm{C}_{14} \mathrm{H}_{30}$ & 198.39 & 8.157 & 8.473 & 8.582 & 9.164 \\
\hline Pentadecane & $\mathrm{C}_{15} \mathrm{H}_{32}$ & 212.41 & 7.271 & 6.967 & 7.641 & 7.525 \\
\hline Hexadecane & $\mathrm{C}_{16} \mathrm{H}_{34}$ & 226.44 & 4.366 & 3.882 & 4.584 & 4.189 \\
\hline Heptadecane & $\mathrm{C}_{17} \mathrm{H}_{36}$ & 240.47 & 5.673 & 4.725 & 5.954 & 5.096 \\
\hline Octadecane & $\mathrm{C}_{18} \mathrm{H}_{38}$ & 254.50 & 4.897 & 3.850 & 5.138 & 4.153 \\
\hline Nonadecane & $\mathrm{C}_{19} \mathrm{H}_{40}$ & 268.53 & 3.129 & 2.349 & 3.282 & 2.532 \\
\hline Icosane & $\mathrm{C}_{20} \mathrm{H}_{42}$ & 282.55 & 3.014 & 2.163 & 3.161 & 2.331 \\
\hline Henicosane & $\mathrm{C}_{21} \mathrm{H}_{44}$ & 296.58 & 2.779 & 1.885 & 2.912 & 2.031 \\
\hline Docosane & $\mathrm{C}_{22} \mathrm{H}_{46}$ & 310.61 & 2.510 & 1.624 & 2.631 & 1.751 \\
\hline Tricosane & $\mathrm{C}_{23} \mathrm{H}_{48}$ & 324.63 & 1.918 & 1.190 & 2.009 & 1.282 \\
\hline Tetracosane & $\mathrm{C}_{24} \mathrm{H}_{50}$ & 338.66 & 1.559 & 0.93 & 1.632 & 1.000 \\
\hline Pentacosane & $\mathrm{C}_{25} \mathrm{H}_{52}$ & 352.69 & 1.314 & 0.752 & 1.375 & 0.809 \\
\hline Hexacosane & $\mathrm{C}_{26} \mathrm{H}_{54}$ & 366.71 & 1.44 & 0.791 & 1.507 & 0.852 \\
\hline Heptacosane & $\mathrm{C}_{27} \mathrm{H}_{56}$ & 380.74 & 1.610 & 0.849 & 1.684 & 0.913 \\
\hline Octacosane & $\mathrm{C}_{28} \mathrm{H}_{58}$ & 394.77 & 1.692 & 0.860 & 1.771 & 0.925 \\
\hline Nonacosane & $\mathrm{C}_{29} \mathrm{H}_{60}$ & 408.80 & 1.902 & 0.934 & 1.990 & 1.004 \\
\hline Triacontane & $\mathrm{C}_{30} \mathrm{H}_{62}$ & 422.82 & 1.436 & 0.681 & 1.501 & 0.732 \\
\hline Hentriacontane & $\mathrm{C}_{31} \mathrm{H}_{64}$ & 436.85 & 1.309 & 0.600 & 1.369 & 0.645 \\
\hline Dotriacontane & $\mathrm{C}_{32} \mathrm{H}_{66}$ & 450.88 & 1.213 & 0.539 & 1.269 & 0.580 \\
\hline Tritriacontane & $\mathrm{C}_{33} \mathrm{H}_{68}$ & 464.90 & 1.086 & 0.468 & 1.135 & 0.503 \\
\hline Tetratriacontane & $\mathrm{C}_{34} \mathrm{H}_{70}$ & 478.93 & 0.943 & 0.395 & 0.985 & 0.424 \\
\hline Pentatriacontane & $\mathrm{C}_{35} \mathrm{H}_{72}$ & 492.96 & 0.411 & 0.168 & 0.430 & 0.179 \\
\hline Hexatriacontane & $\mathrm{C}_{36} \mathrm{H}_{74}$ & 506.98 & 0.270 & 0.107 & 0.280 & 0.114 \\
\hline Heptatriacontane & $\mathrm{C}_{37} \mathrm{H}_{76}$ & 520.99 & 0.147 & 0.057 & 0.153 & 0.061 \\
\hline Octatriacontane & $\mathrm{C}_{38} \mathrm{H}_{78}$ & 535.03 & 0.157 & 0.059 & 0.164 & 0.063 \\
\hline Nonatriacontane & $\mathrm{C}_{39} \mathrm{H}_{80}$ & 549.05 & 0.070 & 0.026 & 0.074 & 0.028 \\
\hline Tetracontane plus & $\mathrm{C}_{40} \mathrm{H}_{82}$ & 563.08 & 0.005 & 0.018 & 0.057 & 0.020 \\
\hline \multicolumn{3}{|c|}{ Total } & 100.000 & 100.000 & 100.000 & 100.000 \\
\hline \multicolumn{3}{|c|}{ Mean Molecular Weight } & \multicolumn{2}{|c|}{197.359} & \multicolumn{2}{|c|}{ 202.877 } \\
\hline
\end{tabular}




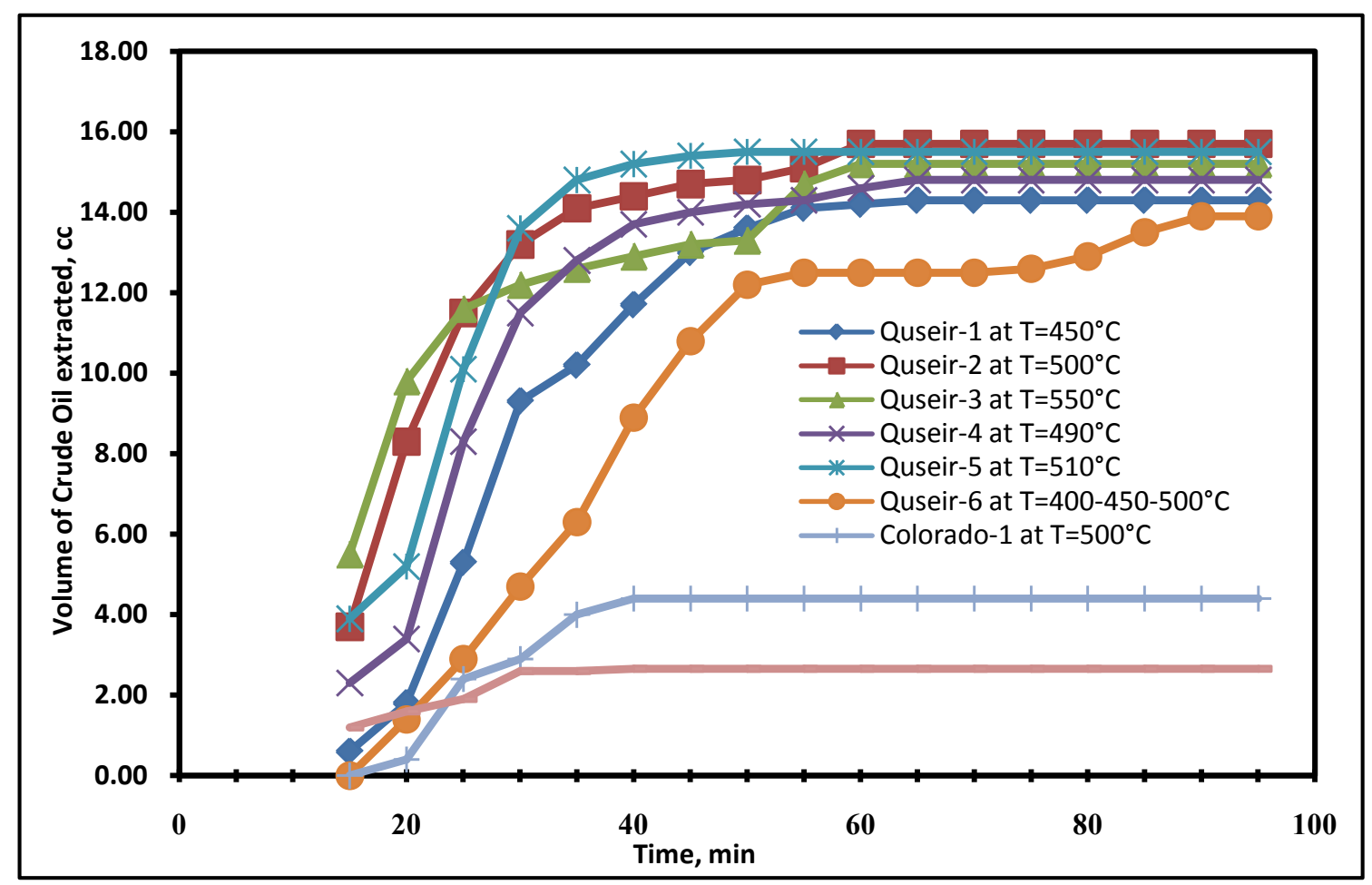

Figure 6. Relationship between volumes of Oil extracted versus Time for different shale oil samples.

\section{References}

[1] El-Sabagh, S.M., Basta, J.S., Ahmed, F.S. and Barakat, M.A. (2012) Characterization of Selected Egyptian Oil Shales from the Red Sea. Fact Sheet: Oil Shale and the Environment, DOE Office of Petroleum Reserves, 22 December.

[2] Demirbas, A. (2009) Political, Economic and Environmental Impacts of Biofuels: A Review. Applied Energy, 86, 108117. http://dx.doi.org/10.1016/j.apenergy.2009.04.036

[3] Darwish, M. (1984) Optimistic Hydrocarbon Potentialities of the Oil Shale in the Quseir-Safaga Land Stretch, Egypt. Faculty of Science Bulletin, 6, 107-117.

[4] Al-Wakeel, M.I. and El-Adly, R.A. (2005) A Novel Application of Egyptian Oil Shale as Filler in the Production of Lithium Lubricating Grease. Energy Sources, Part A: Recovery, Utilization, and Environmental Effects, 27, 1511-1522.

[5] Abdelrahman, A.A. and Aly, I.H. (1994) Thermal Behaviour of Oil Shale. The 4th Mining, Petroleum and Metallurgy Conference, Assiut, 5-7 February, 201-214.

[6] Country Analysis Briefs. (2012) Energy Information Administration (EIA). http://www.eia.gov/countries/country-data.cfm?fips=EG

[7] Abdelrahman, A.A. and Khaled, K.A. (1988) Preliminary Evaluation of Some Black Shales of the Eastern Desert of Egypt. The 3rd Conference of Chemical Engineering, TESCE, Cairo.

[8] Denning, D. (2012) Oil Shale Reserves. The Daily Reckoning, N.D. Egypt Oil Imports. http://www.indexmundi.com/Egypt/oil imports.html

[9] Sykes, R. and Snowdon, L.R. (2002) Guidelines for Assessing the Petroleum Potential of Coaly Source Rocks Using Rock-Eval Pyrolysis. Organic Geochemistry, 33, 1441-1455. http://dx.doi.org/10.1016/S0146-6380(02)00183-3

[10] Chillingarian, G., Wen, C.S. and Yen, T.F. (1978) Properties and Structure of Bitumens. In: Bitumens, Asphalts and Tar Sands, Elsevier, Armsterdam, 155-190.

[11] Altun, N.E., Hicyilmaz, C., Hwang, J.Y. and Bagci, A.S. (2006) Evaluation of a Turkish Low Quality Oil Shale by Flotation as a Clean Energy Source: Material Characterization and Determination of Flotation Behavior. Fuel Processing Technology, 87, 783-791. http://dx.doi.org/10.1016/j.fuproc.2006.04.001

[12] Behar, F., Beaumont, V. and De Penteado, B.H.L. (2001) Rock-Eval 6 Technology: Performances and Developments. Oil \& Gas Science and Technology, 56, 111-134. http://dx.doi.org/10.2516/ogst:2001013 
[13] Vandenbroucke, M. and Largeau, C. (2007) Kerogen Origin, Evolution and Structure. Organic Geochemistry, 38, 719-833.

[14] Tissot, B.P. and Welte, D.H. (1984) Petroleum Formation and Occurrence. 2nd Edition, Springer-Verlag, Berlin, 699 p. 